\title{
Influence of Red Pepper (Capsicum annuum) Addition on Bioenergy Production in Microbial Fuel Cells
}

\author{
Sohyun Chang1, Min Jae Shin1, Yujin Kim², Sung Jun Jang2, Seog In Moon³, Seoyeon Jeong3, \\ Richard Shim ${ }^{3}$, Fengjun Shen', Sara Kang1, Paul S. Chung ${ }^{2,3}$
}

${ }^{1}$ School of Arts \& Sciences, Johns Hopkins University, Baltimore, MD, USA

${ }^{2}$ Fuzbien Technology Institute, Rockville, MD, USA

${ }^{3}$ Youth with Talents, Fairfax, VA, USA

Email:paulschung08@gmail.com

How to cite this paper: Chang, S.-H., Shin, M.J., Kim, Y.-J., Jang, S.J., Moon, S.I., Jeong, S.-Y., Shim, R., Shen, F.-J., Kang, S. and Chung, P.S. (2019) Influence of Red Pepper (Capsicum annuum) Addition on Bioenergy Production in Microbial Fuel Cells. Journal of Sustainable Bioenergy Systems, 9, 179-188. https://doi.org/10.4236/jsbs.2019.94012

Received: September 19, 2019

Accepted: December 20, 2019

Published: December 23, 2019

Copyright $\odot 2019$ by author(s) and Scientific Research Publishing Inc. This work is licensed under the Creative Commons Attribution International License (CC BY 4.0).

http://creativecommons.org/licenses/by/4.0/

\begin{abstract}
The current study was performed to evaluate the beneficial effect in the power output of microbial fuel cells (MFCs) through supplementation of dried red pepper (Capsicum annuum) powder into the anodic chamber. Mediator-less H-type MFCs were set up where the anode chamber contained rumen microorganisms as inocula on cellulose (Avicel) and the cathode chamber of phosphate buffered saline ( $\mathrm{pH}$ 7.4), both separated by cation exchange membrane. Electrical power generation in MFC was monitored daily over a 10-day period and the accumulated amounts and components of gaseous byproducts were measured at the end of $10 \mathrm{~d}$ operation of MFC. For both groups of MFCs with red pepper and the control, the head space gases collected were methane and $\mathrm{CO}_{2}$, and its volume and composition were similar between treatments. Methane and $\mathrm{CO}_{2}$ produced for $10 \mathrm{~d}$ operation were 210.7 and $106.5 \mathrm{~mL}$, respectively, in MFC. The addition of red pepper powder caused an average power density to increase from $24.0 \mathrm{~mW} / \mathrm{m}^{2}$ to $39.6 \mathrm{~mW} / \mathrm{m}^{2}(\mathrm{P}<0.0001)$. The greatest power density was 25.9 and $35.6 \mathrm{~mW} / \mathrm{m}^{2}$ for control and bellflower, respectively. This study provides the strong evidence that red pepper (Capsicum annuum) supplementation might modify the anaerobic fermentation characteristics of rumen microorganisms in anode chamber and improve the cellulosic bioenergy production in MFC.
\end{abstract}

\section{Keywords}

MFC, Capsicum annuum, Bioenergy Production 


\section{Introduction}

Fossil fuels such as petroleum, coal and natural gas are limited resources that will be eventually depleted and are not renewable in short term, however have served as the main energy resources for the past century [1] and represent around $79.4 \%$ of the global primary energy use in 2001 [2]. Fossil fuel combustion and natural gas and petroleum systems generate tremendous amount of greenhouse gases such as $\mathrm{CO}_{2}$, methane $\left(\mathrm{CH}_{4}\right)$ and nitrous oxide $\left(\mathrm{N}_{2} \mathrm{O}\right)$ to atmosphere [3] and represent $94 \%$ to $96 \%$ of total greenhouse emission in the USA [4]. Greenhouse gases absorb infrared radiation and consequently result in global warming. Demands on technologies generating clean and sustainable energy sources that would replace or displace fossil fuels are increasing for these energy and environmental concerns [5].

Cellulosic biomass is particularly attractive renewable resources for clean and sustainable energy production because of its low cost, abundance [6] [7] and neutral carbon balance [8]. Cellulose is a significant component in the annual production of 1.3 billion dry tons of biomass feedstock, 250 million tons of municipal solid wastes and 40 billion cubic meters waste water [9]. Cellulosic biomass can be used in the production of bioethanol [10] biodiesel [11] and hydrogen and electricity [8].

The direct conversion of biomass to electric energy through microbial fuel cells (MFCs) system or to biohydrogen through microbial electrolysis cells (MECs) system is the potential clean and sustainable energy production representing alternative methods of renewable energy recovery [12]. MFCs and MECs are bioelectrochemical reactors that convert wide range of renewable biomass and wastewaters using electrochemically active microorganisms as biocatalysts directly into electricity [12] or biohydrogen [13] that are endowed with tremendous electron donor versatility including glucose, acetate, and lactate [14] [15] [16]; municipal and industrial wastewaters [17] [18] and cellulose [1] [19] [20] [21] [22]. Electrochemically active microorganisms in MFCs or MECs transfer electrons to anode and initiate electric current, however none of them showed cellulolytic activity to directly generate electrons but require products of cellulose hydrolysis as electron donors [14] [23]. With the lack of an isolated microorganism providing both cellulose lysis and solid extracellular electron acceptor reduction, mixed microorganisms have been tested as biocatalysts for use in MFCs including mixed cultures from sea floor sediments [24], municipal and industrial wastewater or anaerobic digester [25] soil [1], [26] and rumen microbiota [22].

The rumen microbiota contains both strict and facultative anaerobes, which effectively hydrolyze cellulose, and conserve energy via anaerobic respiration or fermentation [27] and have been used for enhancing anodic efficiency [22]. However reduction in power production due to loss of substrate to methanogens makes methanogenesis a serious performance limitation in MFCs. Red peppers (Capsicum annuum) contain capsaicin (8-methyl-N-vanillyl-6-nonenamide; $\mathrm{C} 18 \mathrm{H} 27 \mathrm{NO} 3$ ) 
which is a carotenoid [28] and have antioxidant activity [29]. Capsaicin addition has modified microbial fermentation characteristics. Dose of capsaicin decreased intestinal gas production in patients with irritable bowel syndrome [30]. When capsicum oil containing capsaicin was added into rumen microbial fermentation, the ammonia nitrogen concentration was reduced, total VFA production and the propionate proportion were increased, and the acetate proportion and acetate-to-propionate ratio was reduced at higher acidity ( $\mathrm{pH}$ 5.5), while the total VFA and ammonia $\mathrm{N}$ concentrations were reduced and the acetate-to-propionate ratio was increased at lower acidity ( $\mathrm{pH}$ 7.0) [31].

Therefore, we hypothesized that addition of red pepper (Capsicum annuum) powder which has antioxidant activity and contains capsaicin into anode of MFCs would decrease methanogenesis and increase power generation. In the current study, we established MFCs using rumen mixed microorganisms as biocatalysts to generate electricity from cellulose and investigate the effects of red pepper powder on anolyte gas production and power production.

\section{Materials and Methods}

1) Microorganisms and culture media: The rumen fluid collected from dry dairy cow was filtered through 4 layers of cheese cloth and glass wool to remove feed debris while flushing $\mathrm{CO}_{2}$ gas through heated copper column, and maintained anaerobically by flushing and bubbling with $\mathrm{CO}_{2}$ gas through heated copper column until transferred to MFCs.

A medium containing $\mathrm{KH}_{2} \mathrm{PO}_{4}, 0.48 \mathrm{~g} ; \mathrm{K}_{2} \mathrm{HPO}_{4}, 0.48 \mathrm{~g}$; $\left(\mathrm{NH}_{4}\right)_{2} \mathrm{SO}_{4}, 0.48 \mathrm{~g}$; $\mathrm{NaCl}, 0.96 \mathrm{~g}$; Trypticase, 5.0 g; yeast extract, $1.0 \mathrm{~g}$; isobutyric acid, isovaleric acid, and DL-2methylbutyric acid, $0.1 \mathrm{ml}$ of each; cysteine hydrochloride, $0.5 \mathrm{~g}$; $\mathrm{CaCl}_{2} \cdot 2 \mathrm{H}_{2} \mathrm{O}, 0.13 \mathrm{~g} ; \mathrm{MgSO}_{4} \cdot 7 \mathrm{H}_{2} \mathrm{O}, 0.2 \mathrm{~g} ; \mathrm{Na}_{2} \mathrm{CO}_{3}, 4.0 \mathrm{~g}$; sodium fumarate, $1.0 \mathrm{~g}$, and resazurin, $1.0 \mathrm{mg}$ per $1 \mathrm{~L}$ of volume with distilled deionized (dd) $\mathrm{H}_{2} \mathrm{O}$ was prepared anaerobically [32] and autoclaved at $121^{\circ} \mathrm{C}$ for $30 \mathrm{~min}$ and stored at room temperature until transferred to MFCs.

Phosphate buffered saline (PBS) was prepared by dissolving $\mathrm{NaCl}, 8 \mathrm{~g} ; \mathrm{KCl}$, $0.2 \mathrm{~g} ; \mathrm{Na}_{2} \mathrm{HPO}_{4}, 1.44 \mathrm{~g}$; and $\mathrm{KH}_{2} \mathrm{PO}_{4}, 0.24 \mathrm{~g}$ in $800 \mathrm{ml} \mathrm{dd} \mathrm{H}_{2} \mathrm{O}$ and adjusting $\mathrm{pH}$ to 7.4 and volume to $1 \mathrm{~L}$ with $\mathrm{dd}_{2} \mathrm{O}$. $\mathrm{PBS}$ was autoclaved at $121^{\circ} \mathrm{C}$ for $30 \mathrm{~min}$ and stored at room temperature until transferred to MFCs.

2) Microbial Fuel Cells: Microbial fuel cell was constructed using two 125 $\mathrm{mL}$-volume glass bottles clamped at branched tubular bridge and separated with a cation exchange membrane (CMI-7000S, Membranes International Inc., NJ). Two gram of cellulose (Avicel PH-101, Sigma-Aldrich, MO), $80 \mathrm{~mL}$ of anaerobic medium and $20 \mathrm{~mL}$ of stained rumen fluid were transferred to the anode chamber and suspended by agitation. Graphite flat stick $\left(12 \mathrm{~cm}^{2}\right)$ connected with copper wire was placed in the middle of anode chamber and the butyl rubber stopper was placed to prevent air contamination. $100 \mathrm{~mL}$ PBS was transferred to the cathode chamber and a graphite flat stick $\left(12 \mathrm{~cm}^{2}\right)$ connected with copper wire was placed in the middle. The cathode chamber was capped with butyl rubber stop- 
per but was made open to air through a tubing on the stopper. Anode and cathode were connected externally through a copper wire and a load resistor (300 $\mathrm{ohm})$. MFCs were operated in a water bath at $39^{\circ} \mathrm{C}$ for $9 \mathrm{~d}$ prior to treatment inoculation

After $9 \mathrm{~d}$ of MFC pretrial operation and before the treatments were added, current density of MFCs was $210.3 \pm 4.23 \mathrm{~mA} / \mathrm{m}^{2}$. MFCs for treatment group received $0.1 \mathrm{~g}$ dried red pepper powder (CJ CheilJedang, Seoul, Korea) in anode chambers at $\mathrm{d} 0$. All anode chamber stoppers were open to the atmosphere in order to equalize pressure and remove headspace gas, then $2 \mathrm{~L}$-volume Mylar balloons were connected to each anode chamber to collect gases produced.

3) Measurements and calculation: During the experimental period, voltage across external resistor, end point potential and current were measured daily using a digital multimeter. The power density $(\mathrm{P})$ was calculated using an equation: $\mathrm{P}=\mathrm{I} \times \mathrm{V} / \mathrm{A}$, where $\mathrm{I}=$ current, $\mathrm{V}=$ voltage, $\mathrm{R}=$ external resistance $(\mathrm{Ohm})$, and $\mathrm{A}\left(\mathrm{m}^{2}\right)=$ the projected area of the anode.

In the end of operation at $\mathrm{d} 10$, the volumes of gas produced from anode chamber in Mylar balloons were measured using a $250 \mathrm{~mL}$-glass syringe. Methane and $\mathrm{CO}_{2}$ compositions were analyzed using an Agilent 6890 series gas chromatograph equipped with a thermal conductivity detector and a stainless steel packed column containing 60/80 Carboxen 1000 (12390-U Supelco, Sigma-Aldrich, MO).

4) Statistical analyses: Red pepper effects on electricity generation, gas production and gas composition were analyzed using the one-way ANOVA procedure of JPM 14.1.0 (SAS Institute Inc., NC). Significance was declared at P < 0.05 .

\section{Results and Discussion}

\subsection{Electricity Generation}

During the $9 \mathrm{~d}$ pretrial period MFCs established with $20 \mathrm{~mL}$ of stained rumen fluid, $80 \mathrm{~mL}$ of anaerobic medium and $2 \% \mathrm{w} / \mathrm{v}$ cellulose (Avicel ${ }^{\circ}$ ) were stabilized, and voltage across resistor 109 and $107 \mathrm{mV}(\mathrm{P}=0.8762)$ and open circuit voltage (end point potential) were 417 and $419 \mathrm{mV}(\mathrm{P}=0.9789)$ for control and pepper group MFCs, respectively, prior to treatment addition. Voltages across resistor and end point potential (Table 1) in control MFCs were steady and averages were $111 \pm 6.4$ and $405 \pm 35.6 \mathrm{mV}$, respectively, during 10d operation. In MFCs received red pepper powder, voltages across resistor were higher $(\mathrm{P}<$ 0.05 ) for $\mathrm{d} 3$ through $\mathrm{d} 9$ than for $\mathrm{d} 0$ to $\mathrm{d} 2$, and end point potentials were also higher $(\mathrm{P}<0.05)$ for $\mathrm{d} 3$ though $\mathrm{d} 10$ except $\mathrm{d} 5$ than for $\mathrm{d} 0$ and $\mathrm{d} 2$. Red pepper group yielded greater $(\mathrm{P}<0.05)$ voltage across resistor and end point potential than control group on d 5, 6 and 9, and on d 1, 4, 7 and 10, respectively.

Power density (power normalized to the electrode surface area) is a critical parameter determining the MFCs bioelectrochemical performances [33]. Power density in control group was steady with operation time $(\mathrm{P}=0.9399)$ at between 
Table 1. Closed circuit voltage across $300 \mathrm{ohms}$ resistor and terminal voltage measured from microbial fuel cells established with strained rumen fluid and $2 \mathrm{~g}$ of cellulose with or without red pepper (Capsicum annuum: PEP) addition.

\begin{tabular}{ccccccccc}
\hline \multirow{2}{*}{ Day } & \multicolumn{3}{c}{ Voltage across resistor (300 ohms), $\mathrm{mV}$} & \multicolumn{3}{c}{ Open circuit voltage, $\mathrm{mV}$} \\
\cline { 2 - 8 } & Control & PEP & SEM $^{1}$ & $\mathrm{P}^{2}$ & Control & PEP & SEM $^{1}$ & $\mathrm{P}^{2}$ \\
\hline 0 & 108.5 & $107.0^{\mathrm{b}}$ & 0.0060 & 0.8762 & 417.0 & $418.5^{\mathrm{de}}$ & 0.0355 & 0.9789 \\
1 & 111.0 & $108.5^{\mathrm{b}}$ & 0.0028 & 0.5876 & 402.5 & $458.5^{\text {cde }}$ & 0.0040 & 0.0102 \\
2 & 110.0 & $107.5^{\mathrm{b}}$ & 0.0057 & 0.7846 & 351.0 & $406.0^{\mathrm{e}}$ & 0.0099 & 0.0594 \\
3 & 110.5 & $133.0^{\mathrm{a}}$ & 0.0057 & 0.1083 & 406.0 & $538.0^{\mathrm{ab}}$ & 0.0326 & 0.1037 \\
4 & 109.0 & $133.5^{\mathrm{a}}$ & 0.0049 & 0.0718 & 409.5 & $511.0^{\mathrm{abc}}$ & 0.0102 & 0.0196 \\
5 & 115.0 & $128.5^{\mathrm{a}}$ & 0.0008 & 0.0068 & 406.5 & $475.5^{\mathrm{bcd}}$ & 0.0233 & 0.1714 \\
6 & 104.5 & $134.5^{\mathrm{a}}$ & 0.0034 & 0.0241 & 427.5 & $501.5^{\mathrm{abc}}$ & 0.0293 & 0.2156 \\
7 & 110.0 & $135.5^{\mathrm{a}}$ & 0.0048 & 0.0631 & 409.5 & $518.0^{\mathrm{abc}}$ & 0.0120 & 0.0237 \\
8 & 114.0 & $126.5^{\mathrm{a}}$ & 0.0048 & 0.2042 & 393.5 & $515.0^{\mathrm{abc}}$ & 0.0290 & 0.0975 \\
9 & 115.5 & $128.5^{\mathrm{a}}$ & 0.0018 & 0.0364 & 411.5 & $497.5^{\mathrm{abc}}$ & 0.0143 & 0.0513 \\
10 & 115.5 & $123.0^{\mathrm{ab}}$ & 0.0028 & 0.1948 & 421.5 & $543.5^{\mathrm{a}}$ & 0.0112 & 0.0165 \\
$\mathrm{SEM}^{1}$ & 5.41 & 2.98 & & & 28.90 & 11.01 & & \\
$\mathrm{P}^{3}$ & 0.9373 & $<0.0001$ & & & 0.8668 & $<0.0001$ & & \\
\hline
\end{tabular}

${ }^{\text {abcde }}$ Means within a treatment with different superscripts differ, $\mathrm{P}<0.05 .{ }^{1}$ Standard error of means. ${ }^{2} \mathrm{P}$-value: probabilities that treatments effect is not significant within the day. ${ }^{3} \mathrm{P}$-value: probabilities that day effect is not significant within the treatment.

21.2 and $25.9 \mathrm{~mW} / \mathrm{m}^{2}$ (Figure 1), however in red pepper group it changed $(\mathrm{P}<$ 0.0001) with operation time. Power density increased after $\mathrm{d} 3$ and was maintained until $\mathrm{d} 9$ in red pepper group. Power density in red pepper group was greater $(\mathrm{P}<0.05)$ than in control group at $\mathrm{d} 5,6$ and 9 . Power density during $10 \mathrm{~d}$ operation was also greater $(\mathrm{P}=0.0009)$ in red pepper group with average of $30.1 \mathrm{~mW} / \mathrm{m}^{2}$ than in control group $\left(24.0 \mathrm{~mW} / \mathrm{m}^{2}\right)$. In a similar experiment performed with sole rumen fluid as anolyte [22] the highest and stable power density were 55 and $26.7 \mathrm{~mW} / \mathrm{m}^{2}$, respectively, however in their setup, aerobic potassium ferricyanide solution $\left(50 \mathrm{mM} \mathrm{K}_{3} \mathrm{Fe}(\mathrm{CN})_{6}\right)$ had been employed as the catholyte to enhance oxygen reduction while the current MFCs were constructed using PBS which is nontoxic and environmentally friendly as catholyte. Furthermore, the performance in the current study could be restricted by the intrinsic large internal resistance of $\mathrm{H}$-type fuel cells with long distance between the anode and cathode and small surface area of the cation exchange membrane [12]. Thus, the performance of the current MFCs will not stand a direct comparison to the previous report, but the stable power density of $24.0 \mathrm{~mW} / \mathrm{m}^{2}$ in control group is close to the previously reported value in the MFC system established with the similar anolyte.

\subsection{Gas Production and Composition}

Total gas production, $319 \mathrm{~mL}$ vs. $316 \mathrm{~mL}$ for control and red pepper group, respectively, were similar $(\mathrm{P}=0.8223)$ in anode chamber for $10 \mathrm{~d}$ operation of 


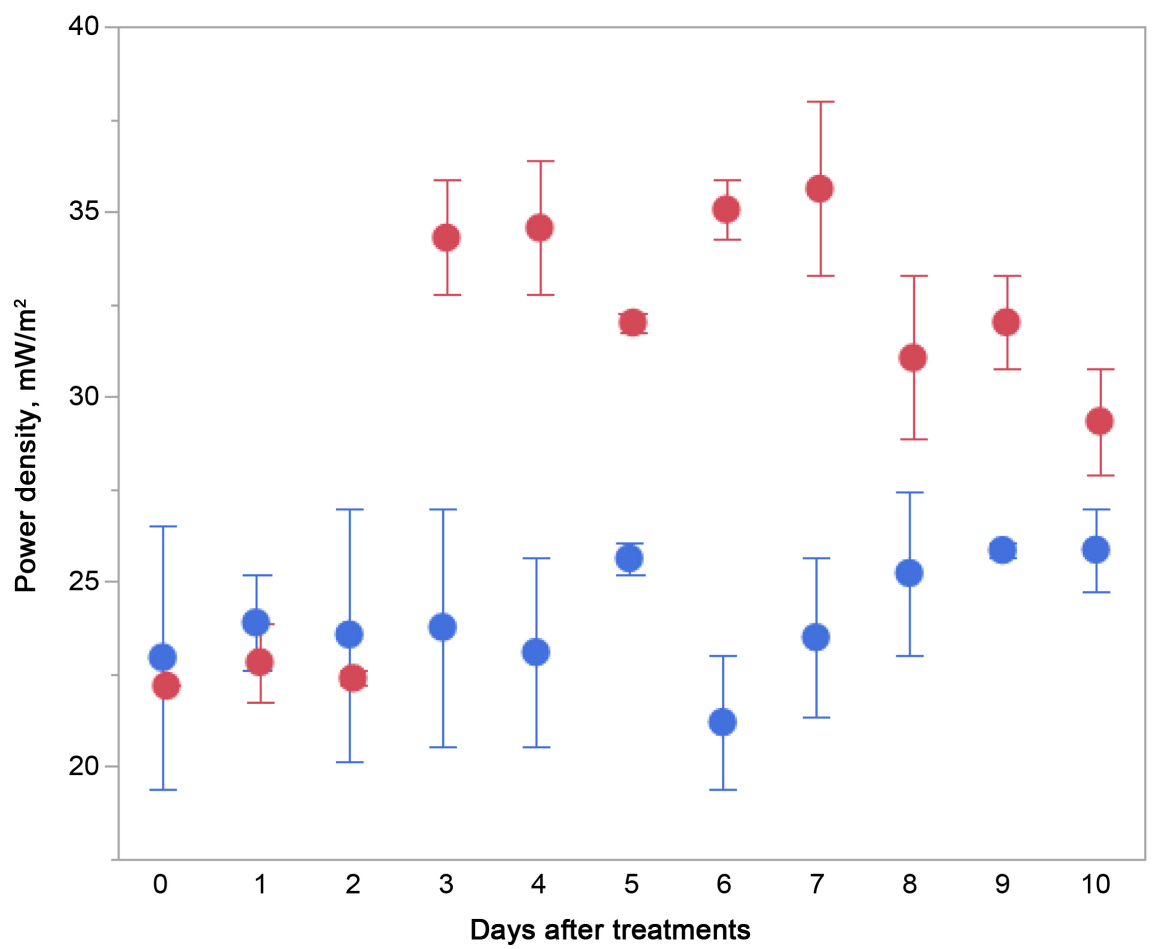

Figure 1. Power densities over 10 day operation of MFCs. Anode chambers were established for $9 \mathrm{~d}$ with strained rumen fluid and $2 \mathrm{~g}$ of cellulose (Avicel ${ }^{\circledR}$ ), then $100 \mathrm{mg}$ of red pepper (Capsicum annuum) was added to anode chamber of treatment group. After treatment was added, microbial fuel cells were incubated at $39^{\circ} \mathrm{C}$. And power generation over $300 \mathrm{ohm}$ resistor was measured every $24 \mathrm{hrs}$. Power densities are presented as least square means $(n=2)$ with standard error of mean for control $(O)$ and red pepper treatment $(\bigcirc) .{ }^{a b c}$ Means within red pepper treatment with different superscripts differ $(\mathrm{P}<0.05)$. ${ }^{\star}$ Means between control and red pepper treatment differ $(\mathrm{P}<0.05)$.

MFCs (Figure 2). Methane $(\mathrm{P}=0.8960)$ and $\mathrm{CO}_{2}(\mathrm{P}=0.6862)$ productions were also not different between control and treatment group, and volumes were 211 and $107 \mathrm{~mL}$ in control group, respectively, and 210 and $106 \mathrm{~mL}$ in red pepper group, respectively.

Once sole proton donor substrates, cellulose, were degraded by cellulolytic microorganisms in the anolyte, the ideal glucose decomposition in MFCs is into $\mathrm{CO}_{2}$, proton and electron in anode chamber under anaerobic condition $\left(\mathrm{C}_{6} \mathrm{H}_{12} \mathrm{O}_{6}+6 \mathrm{H}_{2} \mathrm{O} \rightarrow 6 \mathrm{CO}_{2}+24 \mathrm{H}^{+}+24 \mathrm{e}^{-}\right)$[34] by symbiotic microorganisms. The electrons and the protons move to cathode via the external electrical circuit and the cation exchange membrane, respectively, then reduce oxygen and produce water $\left(24 \mathrm{H}^{+}+24 \mathrm{e}^{-}+6 \mathrm{O}_{2} \rightarrow 12 \mathrm{H}_{2} \mathrm{O}\right)$. Overall scheme in whole MFC in this case is $\mathrm{C}_{6} \mathrm{H}_{12} \mathrm{O}_{6}+6 \mathrm{O}_{2} \rightarrow 6 \mathrm{CO}_{2}+6 \mathrm{H}_{2} \mathrm{O}+$ Electrical energy [34]. Cellulose fermentation products by rumen fluid like the anolyte in the current MFCs are mainly volatile fatty acids including acetate, propionate, and butyrate [35] and these products are readily metabolized and converted to electric energy by electrochemically active microbial community on electrode [36]. However, in the most of MFCs, both acetoclastic methanogenesis $\left(\mathrm{CH}_{3} \mathrm{COO}^{-}+\mathrm{H}^{+} \rightarrow \mathrm{CH}_{4}+\mathrm{CO}_{2}\right)$ 


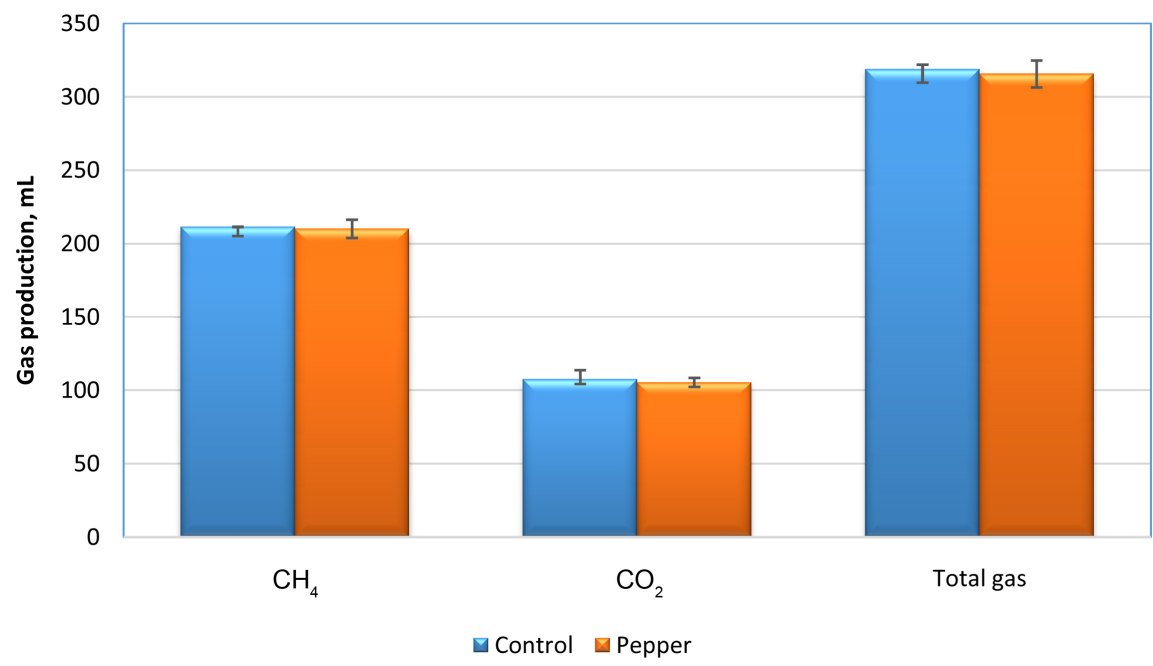

Figure 2. Components and total volume of gases produced in the anode chamber of microbial fuel cells for $10 \mathrm{~d}$ operation. Anode chambers were established for $9 \mathrm{~d}$ with strained rumen fluid and $2 \mathrm{~g}$ of cellulose $\left(\right.$ Avicel $^{\circledR}$ ), then $100 \mathrm{mg}$ of red pepper (Capsicum annuum) was added to anode chamber of treatment group. After treatment was added, microbial fuel cells were incubated at $39^{\circ} \mathrm{C}$ and gases produced in anode chamber were collected in externally connected Mylar balloons for $10 \mathrm{~d}$. Methane, $\mathrm{CO}_{2}$ and total gas are presented as least square means $(n=2)$ with standard deviation.

and hydrogenotrophic methanogenesis $\left(4 \mathrm{H}_{2}+\mathrm{CO}_{2} \rightarrow \mathrm{CH}_{4}+2 \mathrm{H}_{2} \mathrm{O}\right)$ occurred and reduced the energy production. Both methanogeneses require exogenous energy consumption [37] and reduce the flow of proton and electron to cathode, therefore methane production is regarded as an inefficient process which detracts from electricity generation.

In the current study, similar quantity and overall pathway of cellulose fermentation in all group can be deduced from the production of total gas, methane and $\mathrm{CO}_{2}$, which were not different between control and red pepper MFCs. Therefore, the increase in power generation by red pepper addition in the current study may result from changes in intermediate products which were observed in previous capsaicin studies in rumen fluid fermentation [31] and/or the possible favorable environment for electrochemically active microorganisms which can be caused by antioxidant activity of red peppers [29].

\section{Conclusion}

Cellulosic biomass is the most desirable resource for clean and renewable biofuel production because of its abundance and carbon neutral characteristics. In the current study, rumen fluid was used as anolyte in MFCs to generate electricity from cellulose and stable power generation was similar to the previous researches employed rumen. Red pepper powder addition at $0.1 \% \mathrm{w} / \mathrm{v}$ into anolyte increased power generation but did not change gas production or its composition. The amount of cellulolysis, which was deduced from gas production, and overall fermentation pathway, which was reflected from gas composition, were not affected by red pepper addition in MFCs. These results imply that added red 
pepper powder may change the intermediate cellulose fermentation products and/or provide antioxidant activity favorable to electrochemically active microorganisms which transfer electrons to electrode, and increase power generation in MFCs. Further researches are required to investigate the mode and mechanism of red pepper effects on symbiosis and electrode reduction in anode or MFCs.

\section{Acknowledgements}

The authors acknowledge the STEM Research Institute and Youth with Talents for sponsoring this research project (SRI-2018-6).

\section{Conflicts of Interest}

The authors declare no conflicts of interest regarding the publication of this paper.

\section{References}

[1] Hassan, S.H., Kim, Y.S. and Oh, S.E. (2012) Power Generation from Cellulose Using Mixed and Pure Cultures of Cellulose-Degrading Bacteria in a Microbial Fuel Cell. Enzyme and Microbial Technology, 51, 269-273. https://doi.org/10.1016/j.enzmictec.2012.07.008

[2] Goldemberg, J. and Johansson, T.B. (2004) World Energy Assessment Overview: 2004 Update. United Nations Development Programme, New York.

[3] Saratale, G. and Oh, S. (2011) Production of Thermotolerant and Alkalotolerant Cellulolytic Enzymes by Isolated Nocardiopsis sp. KNU. Biodegradation, 22, 905-919. https://doi.org/10.1007/s10532-010-9450-0

[4] EPA (2016) Inventory of U.S. Greenhouse Gas Emissions and Sinks: 1990-2014. https://www.epa.gov/sites/production/files/2016-04/documents/us-ghg-inventory-2 016-main-text.pdf

[5] Levin, D.B., Islam, R., Cicek, N. and Sparling, R. (2006) Hydrogen Production by Clostridium thermocellum 27405 from Cellulosic Biomass Substrates. International Journal of Hydrogen Energy, 31, 1496-1503. https://doi.org/10.1016/j.ijhydene.2006.06.015

[6] Lynd, L.R., Weimer, P.J., van Zyl, W.H. and Pretorius, I.S. (2002) Microbial Cellulose Utilization: Fundamentals and Biotechnology. Microbiology and Molecular Biology Reviews, 66, 506-577. https://doi.org/10.1128/MMBR.66.3.506-577.2002

[7] Schwarz, W.H. (2001) The Cellulosome and Cellulose Degradation by Anaerobic Bacteria. Applied Microbiology and Biotechnology, 56, 634-649. https://doi.org/10.1007/s002530100710

[8] Niessen, J., Schröder, U., Harnisch, F. and Scholz, F. (2005) Gaining Electricity from in Situ Oxidation of Hydrogen Produced by Fermentative Cellulose Degradation. Letters in Applied Microbiology, 41, 286-290. https://doi.org/10.1111/j.1472-765X.2005.01742.x

[9] Perlack, R., Wright, L.L., Turhollow, A.F., Graham, A.F., Stokes, B.J. and Erbach, D.C. (2005) Biomass as Feedstock for a Bioenergy and Bioproducts Industry: The Technical Feasibility of a Billion-Ton Annual Supply. Oak Ridge National Laboratory, Oak Ridge. https://doi.org/10.2172/1216415 
[10] Mielenz, J.R. (2001) Ethanol Production from Biomass: Technology and Commercialization Status. Current Opinion in Microbiology, 4, 324-329. https://doi.org/10.1016/S1369-5274(00)00211-3

[11] Powlson, D.S., Riche, A.B. and Shield, I. (2005) Biofuels and Other Approaches for Decreasing Fossil Fuel Emissions from Agriculture. Annals of Applied Biology, 146, 193-201. https://doi.org/10.1111/j.1744-7348.2005.040056.x

[12] Logan, B.E. and Regan, J.M. (2006) Microbial Fuel Cells-Challenges and Applications. Environmental Science \& Technology, 40, 5172-5180. https://doi.org/10.1021/es0627592

[13] Tremouli, A., Greenman, J. and Ieropoulos, I. (2018) Investigation of Ceramic MFC Stacks for Urine Energy Extraction. Bioelectrochemistry, 123, 19-25. https://doi.org/10.1016/j.bioelechem.2018.03.010

[14] Bond, D.R. and Lovley, D.R. (2003) Electricity Production by Geobacter sulfureducens Attached to Electrodes. Applied and Environmental Microbiology, 69, 1548-1555. https://doi.org/10.1128/AEM.69.3.1548-1555.2003

[15] Liu, H., Cheng, S. and Logan, B.E. (2005) Production of Electricity from Acetate or Butyrate Using a Single-Chamber Microbial Fuel Cell. Environmental Science \& Technology, 39, 658-662. https://doi.org/10.1021/es048927c

[16] Park, D.H. and Zeikus, J.G. (2002) Impact of Electrode Composition on Electricity Generation in a Single-Compartment Fuel Cell Using Shewanella putrefaciens. Applied Microbiology and Biotechnology, 59, 58-61. https://doi.org/10.1007/s00253-002-0972-1

[17] Min, B., Kim, J., Oh, S., Regan, J.M. and Logan, B.E. (2005) Electricity Generation from Swine Wastewater Using Microbial Fuel Cells. Water Research, 39, 4961-4968. https://doi.org/10.1016/j.watres.2005.09.039

[18] Aelterman, P., Rabaey, K., Clauwaert, P. and Verstraete, W. (2006) Microbial Fuel Cells for Wastewater Treatment. Water Science \& Technology, 54, 9-15. https://doi.org/10.2166/wst.2006.702

[19] Ishii, S., Suzuki, S., Norden-Krichmar, T.M., Nealson, K.H., Sekiguchi, Y. and Gorby, Y.A. (2012) Functionally Stable and Phylogenetically Diverse Microbial Enrichments from Microbial Fuel Cells during Wastewater Treatment. PLoS ONE, 7, e30495. https://doi.org/10.1371/journal.pone.0030495

[20] Ren, Z., Ward, T.E. and Regan, J.M. (2007) Electricity Production from Cellulose in a Microbial Fuel Cell Using a Defined Binary Culture. Environmental Science and Technology, 41, 4781-4786. https://doi.org/10.1021/es070577h

[21] Rezaei, F., Richard, T.L., Brennan, R.A. and Logan, B.E. (2007) Substrate-Enhanced Microbial Fuel Cells for Improved Remote Power Generation from Sediment-Based Systems. Environmental Science and Technology, 41, 4053-4058. https://doi.org/10.1021/es070426e

[22] Rismani-Yazdi, H., Christy, A.D., Dehority, B.A., Morrison, M., Yu, Z. and Tuovinen, O.H. (2007) Electricity Generation from Cellulose by Rumen Microorganisms in Microbial Fuel Cells. Biotechnology and Bioengineering, 97, 1398-1407. https://doi.org/10.1002/bit.21366

[23] Lovley, D.R. (2006) Bug Juice: Harvesting Electricity with Microorganisms. Nature Reviews Microbiology, 4, 497-508. https://doi.org/10.1038/nrmicro1442

[24] Bond, D.R., Holmes, D.E., Tender, L.M. and Lovley, D.R. (2002) Electrode-Reducing Microorganisms That Harvest Energy from Marine Sediments. Science, 295, 483-485. https://doi.org/10.1126/science.1066771 
[25] Higgins, S.R., Lopeza, R.J., Pagalingb, E., Yanb, E. and Cooney, M.J. (2013) Towards a Hybrid Anaerobic Digester-Microbial Fuel Cell Integrated Energy Recovery System: An Overview of the Development of an Electrogenic Biofilm. Enzyme and Microbial Technology, 52, 344-351. https://doi.org/10.1016/j.enzmictec.2013.02.017

[26] Rubaba, O., Araki, Y., Yamamoto, S., Suzuki, K., Sakamoto, H., Matsuda, A. and Futamata, H. (2013) Electricity Producing Property and Bacterial Community Structure in Microbial Fuel Cells Equipped with Membrane Electrode Assembly. Journal of Bioscience and Bioengineering, 116, 106-113.

https://doi.org/10.1016/j.jbiosc.2013.01.019

[27] Krause, D.O., Denman, S.E., Mackie, R.I. and Morrison, M. (2003) Opportunities to Improve Fiber Degradation in the Rumen: Microbiology, Ecology, and Genomics. FEMS Microbiology Reviews, 27, 663-693. https://doi.org/10.1016/S0168-6445(03)00072-X

[28] Cichewicz, R.H. and Thorpe, P.A. (1996) The Antimicrobial Properties of Chile Peppers (Capsicum Species) and Their Uses in Mayan Medicine. Journal of Ethnopharmacology, 52, 61-70. https://doi.org/10.1016/0378-8741(96)01384-0

[29] Howard, L.R., Talcott, S.T., Brenes, C.H. and Villalon, B. (2000) Changes in Phytochemical and Antioxidant Activity of Selected Pepper Cultivars (Capsicum Species) as Influence by Maturity. Journal of Agricultural and Food Chemistry, 60, 1713-1720. https://doi.org/10.1021/jf990916t

[30] Serra, J. (2012) Intestinal Gas: Has Diet Anything to Do in the Absence of a Demonstrable Malabsorption State? Current Opinion in Clinical Nutrition \& Metabolic Care, 15, 489-493. https://doi.org/10.1097/MCO.0b013e328356662d

[31] Cardozo, P.W., Calsamiglia, S., Ferret, A. and Kamel, C. (2005) Screening for the Effects of Natural Plant Extracts at Different $\mathrm{pH}$ on in Vitro Rumen Microbial Fermentation of a High-Concentrate Diet for Beef Cattle. Journal of Animal Science, 83, 2572-2579. https://doi.org/10.2527/2005.83112572x

[32] Goering, H.K. and Van Soest, P.J. (1970) Forage Fiber Analyses (Apparatus, Reagents, Procedures, and Some Applications). Agriculture Handbook 379. ARS, USDA, Washington DC.

[33] Choi, S. (2015) Microscale Microbial Fuel Cells: Advances and Challenges. Biosensors Bioelectronics, 69, 8-25. https://doi.org/10.1016/j.bios.2015.02.021

[34] Pham, T.H., Rabaey, K., Aelterman, P., Clauwaert, P., De Schamphelaire, L., Boon, N. and Verstraete, W. (2006) Microbial Fuel Cells in Relation to Conventional Anaerobic Digestion Technology. Engineering in Life Sciences, 6, 285-292. https://doi.org/10.1002/elsc.200620121

[35] Leschine, S.B. (1995) Cellulose Degradation in Anaerobic Environments. Annual Review of Microbiology, 49, 399-426. https://doi.org/10.1146/annurev.mi.49.100195.002151

[36] Freguia, S., The, E.H., Boon, N., Leung, K.M., Keller, J. and Rabaey, K. (2010) Microbial Fuel Cells Operating on Mixed Fatty Acids. Bioresource Technology, 101, 1233-1238. https://doi.org/10.1016/j.biortech.2009.09.054

[37] Kaur, A., Boghani, H.C., Michie, I., Dinsdale, R.M., Guwy, A.J. and Premier, G.C. (2014) Inhibition of Methane Production in Microbial Fuel Cells: Operating Strategies Which Select Electrogens over Methanogens. Bioresource Technology, 173, 75-81. https://doi.org/10.1016/j.biortech.2014.09.091 